\title{
Is Finance-Growth Nexus Linear in Selected Countries of Middle East and Northem Africa?
}

\author{
Daouia Chebab ${ }^{1+}$, Nur Syazwani Mazlan¹, Wan Azman Saini Wan Ngah', and Lee Chin ${ }^{1}$ \\ ${ }^{1}$ Universiti Putra Malaysia, Malaysia
}

\begin{abstract}
The present study re-examines the impact of financial development on economic growth in resource-rich Middle East and North Africa (MENA) countries over 1987-2015. Although several studies investigate the finance-growth nexus, none emphasized the nature of this relationship in MENA. In the long run, an inverted U-shaped association between finance and growth is indicated when using pooled mean group estimations. However, the relationship is not significant in the short run. The outcomes suggest that financial development is significantly and positively affiliated with economic growth up to a certain level. After this turning point, additional financial development tends to adversely affect economic growth. The existence of an inverse U-shape association between financial development and economic growth was confirmed by the estimation of the U-test. The outcomes of our study are important to policymakers, in terms of optimizing the necessary and limit of financial development to ensure maximum benefit for the whole economy through the banking sector.
\end{abstract}

Keywords: Economic Growth, Financial Development, MENA, Non-linear, Pooled Mean Group Estimation JEL Classifications: O41, G21

Received 28 September 2019, Revised 28 March 2020, Accepted 31 March 2020

\section{Introduction}

This research aims to examine the correlation between the indicators of financial development and economic growth. The empirical study conducted by Goldsmith (1969) showed a significant correlation between financial development and GDP per capita. This is due to the increased efficiency of financial intermediation before the volume of investment (Bencivenga \& Smith,

\footnotetext{
+Corresponding Author: Daouia Chebab

Ph.D Student in Economics, School of Business and Economics, Universiti Putra Malaysia, UPM Serdang, 43400, Selangor, Malaysia. Email: chdaouia@gmail.com

Co-Author: Nur Syazwani Mazlan

Senior Lecturer, School of Business and Economics, Universiti Putra Malaysia, 43400 UPM Serdang, Selangor, Malaysia. Tel: +603-9769 7578, Email: nur.syazwani@upm.edu.my

Co-Author: Wan Azman Saini Wan Ngah

Associate Professor, School of Business and Economics, Universiti Putra Malaysia, UPM Serdang, 43400, Selangor,

Malaysia. Tel: +603-9769 7628, Email: wazman@upm.edu.my

Co-Author: Lee Chin

Associate Professor, School of Business and Economics, Universiti Putra Malaysia, UPM Serdang, 43400, Selangor, Malaysia. Tel: +603-9769 7769, Email: leechin@upm.edu.my
} 
1991; Grenwood \& Jovanovich, 1990). This positive relationship was supported by the pioneering works of Beck et al. (2000, 2004), Levine et al. (2000), Schumpeter (1911), and King and Levine (1993a), who hypothesized "more finance, more growth."

However, other literature by Robinson (1952) presented that demands for economic growth are the main drivers, whereas Lucas (1988) and others discounted categorically the possibility that growth is impacted by the financial sector. Additionally, recent studies have emphasized that levels of financial development have different impacts on finance-growth nexus. For instance, Rioja and Valev (2004) demonstrated that financial development positively impacts economic growth in countries with intermediate and high financial development. They further concluded that this effect was the highest in the intermediate region.

Nevertheless, the global economic crisis (2007-2008) has urged policymakers and academics to re-evaluate earlier conclusions. The crisis illuminated the probability that deficient financial systems may indirectly and directly reduce savings and favored speculation and dissipating resources, therefore leading to under-investment and the misuse of limited resources. As an outcome, it may lead to a stagnating economy, a rising unemployment rate, and exacerbating poverty.

During the global economic crisis, policymakers and economists were urged to figure out the financial systems' optimal size to ensure sustainable economic growth.

Additionally, the sub-prime mortgage crisis occurred and meant the level of non-performing loans increased since borrowers were unable to repay their loans. Therefore, the global financial crisis affected not only Asian countries but also economies worldwide. Researchers from the International Monetary Fund and the Bank for International Settlement argued that the level of financial development might be beneficial and positive up to certain levels only. Going beyond certain optimal levels might become a drag on growth (Law \& Singh, 2014).

This outcome indicates that the correlation between the finance-growth nexus is not linear. It represents an inverted U-shape relationship, indicating a turning point in the impact of financial development. Therefore, the impact of financial development on economic growth acquired substantial empirical attention in developed and developing countries. However, to date, research on the relationship itself has remained inconclusive.

As previous studies in the MENA (Middle East and North Africa) region have investigated the determinants of financial development and the causality relationship (Al-Avad \& Harb, 2005; Al-Tamimi et al., 2002; Creane et al., 2004; Kar et al., 2011), this paper attempts to determine the optimal level of financial development and the limit after which more development might dampen economic growth in MENA. This study is motived by the theoretical arguments that declare a non-monotonic relationship between finance and growth (see Law \& Singh, 2014; Samargandi et al., 2014).

This research focuses on selected MENA countries for the following reasons: the first is the richness of the region in terms of natural resources. Out of 12 nations from the Organization 
of the Petroleum Exporting Countries, eight are from MENA. Furthermore, the region has one of the largest natural resource endowments in the world (Majbouri, 2015). The World Bank (2011) highlighted that nearly $55 \%$ of global oil reserves are concentrated in the Middle East. The Middle East, with only $2 \%$ of the world's producing wells, produces over $30 \%$ of the world's crude oil and contains $43 \%$ of the world's conventional gas reserves (BP, 2013). Moreover, the availability of natural oil and gas resources are the main characteristics among MENA countries (World Bank, 2007). Natural resources are considered to be the dominant source of revenue and wealth in the region (Apergis \& Payne, 2014). Furthermore, Samargandi et al. (2014) highlighted that the domination of the oil sector in the whole economy handicaps the extension of service and industrial sectors. Therefore, a tight economic foundation due to possessing too many natural resources prohibits financial deepening (Bhattacharyya \& Hodler, 2014).

The second reason is the mixed results on the relationship between financial development and economic growth in MENA. Kar et al. (2011), by applying the panel Granger causality test, demonstrated that financial development is a crucial determinant of economic growth in MENA. Moreover, they stated that high information, transaction costs, and strict control of the financial sector may prohibit economic growth, which leads to failing to raise a potential effect on economic growth. Conversely, other scholars (Abu-Bader \& Abu-Qarn, 2008; Boulila \& Trabelsi, 2004) illustrated that financial development significantly boosts economic growth.

The third point relates to the reformation and liberalization of the financial sector in MENA over the last two decades (Ben Naceur et al., 2008). These reforms involve several aspects, such as launching programs of credits and lifting restrictions of the governments related to the banking system in terms of interest rate ceilings. According to McKinnon (1973) and Shaw (1973), these aspects may enhance the financial sector and economic growth. Additionally, Gazdar and Cherif (2015) illustrated that growth performance in MENA economies has been unsatisfactory over the past decades, where it witnessed the weakest real GDP per capita worldwide. A possible reason is the non-linearity of the finance-growth nexus.

To understand the connection between the financial system's size and the productivity growth of a given country, a graphical representation (Figure A1, see Appendix) was computed to figure out whether there is a limit where finance is no longer better for economic growth. After measuring the financial development through the ratio of domestic credit to private sector, the association is not monotonic. This means that at low levels of domestic credit, growth is higher. However, a turning point exists where a bigger financial system and further lending deplete economic growth.

The present research contributes in four major segments to the existing literature. First, despite the numerous literatures on the relationship between finance and growth in advanced countries, limited studies have been focused on developing countries. This is because, in advanced countries, the financial sector can ease mobilizing the capital between deficit and surplus agents 
efficiently, which boosts economic growth, whereas the financial sector in developing countries has a lower degree of banking intermediation and is less developed. Among these developing countries, the focus of this paper is on resource-rich MENA countries.

Second, this study adopts the dynamic panel heterogeneity analysis, which was applied by Loayza and Ranciere (2006) on the relationship between financial and growth. The economic growth model is a dynamic process; hence, applying a dynamic panel approach is more appropriate. This is to investigate the short- and long-run impacts of finance on growth, applying the autoregressive distributed lag (ARDL) model, which allows country-specific heterogeneity. Moreover, in econometrics, no single accurate approach for modeling non-linearity exists. Studies have relied on threshold technique estimation for a large sample of countries. However, this paper applied dynamic panel heterogeneity within a small sample to examine the possible non-monotonicity in the finance-growth nexus. Unlike previous studies that pooled many developing countries, this paper used data from MENA countries that usually tend to overlap developing sectors, including finance. Assuming that the financial sector promotes resources' efficient allocation between real and financial, sectors will be inhibited because of limited productive economic activities.

Investigating the possibility of a negative impact of "too much finance" on the MENA economy, this research allows the possibility of a non-monotonic relationship, particularly by performing the quadratic model for the relation between finance and growth. For robustness, the study of Lind and Mehlum (2010) that proposed a test to figure out the existence of a U-shaped or inverted U-shaped relationship is used. This study also highlights the potential impact of oil and gas rents that measure the resource abundance on economic growth.

Third, three proxies of financial development (liquid liabilities, private sector credit, and domestic credit) were applied in the analysis, to apprehend several characteristics of financial development (Law \& Singh, 2014), where other papers (Samargandi et al., 2015) used the principal component analysis. Previous studies that examined the relationship between financial development and economic growth have no uniform argument regarding which measures are most suitable to capture this relationship. Thus, this study applied these three proxies to capture a holistic view of the finance-growth nexus.

Finally, the present research advances the debate in finance and growth literature by suggesting a set of policy actions that will help develop the lagged financial system in MENA.

The present research covers the following points: section 2 reviews the various studies that have investigated the finance-growth nexus, section 3 portrays and presents the data and methodology, section 4 provides an in-depth empirical analysis of findings, section 5 details the robustness checks that were utilized, and section 6 provides a conclusion. 


\section{Literature Review}

The literature on finance-growth nexus can be traced back to the early twentieth century. The pioneering work of Schumpeter and Opie (1934) demonstrated the relation between bankers and entrepreneurs and highlighted how the adoption of new technologies by financial institutions could boost output and growth. Another study developed the ideas of "demand following" and "supply leading" aspects of financial development (Patrick, 1966), whereas McKinnon (1973) and Shaw (1973) asserted that capital markets are not excessively regulated encourage savings. Hence, issues related to the quality and quantity of investments have direct influence on promoting higher economic growth. Subsequently, the emergence of the endogenous growth theory (Lucas, 1988; Romer, 1986) generated renewed interest in the crucial role of financial development in driving economic growth. The above literature indicates that the financial sector plays a positive role in boosting economic growth through the allocation of resources to productive investment, reduction of information, mobilization of savings, diversification of risks, transaction and monitoring costs, and easing the exchange of goods and services. This leads to more efficient allocations of resources, accelerates the accumulation of human and physical capital, and speeds technological progress. For example, Greenwood and Jovanovic (1990) argued that financial intermediaries foster investment and by consequence economic growth. This is by allowing a higher rate of return on capital, where the growth stimulates the extension of financial institutions. Work of Bencivenga and Smith (1991) demonstrated that financial intermediaries authorize agents for channeling savings into investments with high returns that promote growth. Moreover, the intermediaries allow individuals to hold diversified portfolios to moderate risks related to their liquidity needs.

Furthermore, King and Levine (1993a) highlighted the presence of significant and positive relationships between different indicators of financial development and growth in the GDP per capita in a sample of over 80 countries.

Rajan and Zingales (1998) showed that firms in economies with an advanced financial system might obtain inexpensive external funding, which may lead to rising economic growth. Beck et al. (2000) indicated that financial intermediaries exerted a positive and significant impact on overall productivity factor, which influenced the total GDP growth.

Further studies have highlighted the correlation between changes in financial development and economic growth through income levels. Rioja and Valev (2004) demonstrated a non-significant correlation between financial development and growth within low-income countries. However, for middle-income countries, they found a significant positive correlation and a moderate correlation in high-income countries.

Conversely, in their study on the credit extended by banks for the private sector, Cecchetti and Kharroubi (2012) found that the turning point was approximately $90 \%$ of GDP, and they 
suggested that when there is faster growth in the financial sector, the whole economy grows slower. These outcomes point out that fast-growing and large financial sectors could be expensive for the economy because of scarce resources causing the rest of the economy to compete with the rising financial sector. Thus, financial booms are not necessarily growth enhancing. Additional support to Cecchetti and Kharroubi (2012) is the suggestion of Arcand et al. (2012) that the correlation between finance-growth and high-income countries tends to be negative. They mentioned that the negative impact of the finance sector starts when $100 \%$ of GDP is reached by the private sector credit. Arcand et al. also argued about the similarity of their findings with the financial development's "vanishing effect." It suggests that results were not driven by banking crises, output volatility, differences in bank regulation, or by a lack of supervision causing low institutional quality.

Moreover, the results of Beck et al. (2014) argued that the positive impact of finance on growth is limited to a certain critical threshold.

Law and Singh (2014) also recorded that the relationship between finance and growth is an inverted U-shaped from a sample of 87 developed and developing countries from 1980 to 2010. Another study (Samargandi et al., 2015) reported a non-linear relationship between finance and growth in which higher financial development may strengthen economic growth before a certain threshold is reached. Soedarmono et al. (2017) found an inverted U-shaped relationship between financial development and economic growth where financial development was measured by financial deepening and financial intermediation.

Therefore, this inconsistency in the findings between the previous researches has highlighted the necessity to re-estimate the correlation between real economic growth and finance. Further research on the nonlinearities is still unsettled although evidence appears to support an inverted U-shaped relationship.

\section{Data and Methodology}

\section{A. Data analysis}

To examine the long-run relationship between finance and growth, we utilized the annual data of 11-panel natural resource-rich countries1) among the MENA region and over 28 years from 1987 to 2015 . The selection of the starting period was constrained by the availability of data. In this study, the analysis engaged three indicators of financial development.

The three banking sector development indicators have been designated as ratios of the GDP. Private sector credit reflects the private sector value of financial intermediary credits. Liquid

1) Algeria, Iran, Iraq, Bahrain, Kuwait, Oman, Saudi Arabia, United Arab Emirates, Qatar, Libya, and Yemen. 
liabilities measure the overall size of financial intermediaries relative to the size of the economy. Lastly, domestic credit is credit provided by the banking sector to the public and private sectors.

These indicators were utilized because the MENA region is bank based. In this study, the bank-based index is considered for measuring financial development for various reasons. Previous studies stated that developing countries relied more on bank-based financial systems. Therefore, the relationship between the private sector and a well-established bank system is strong, in a way that efficient information obtained by private sectors due to this relationship persuades them to pay their debts regularly and on time (Rajan \& Zingales, 2003).

The estimation model also includes other control variables. The first is the lagged of the dependent variable, which is the initial real GDP that captured the tendency for growth rate across countries. This was obtained from the primary year of every period. Then, natural resource rents captured its effect on economic growth. The third variable is government expenditure, which captured the extent of public goods that have been provided. It reflects the possible bias impacts of taxation and public spending. Human capital variable is included because it has been considered as the main determinant of economic growth in endogenous growth models. The life expectancy proxy was used because the dataset is complete. Theoretical studies argued that longer life expectancy promotes educational investment because a longer time horizon increases the value of investments that pay out over time. Moreover, GraffZivin and Neidell (2013) demonstrated that schooling is the main vehicle for enhancing human capital and absence from school may prevent children from succeeding, which hinders the development of human capital. And lastly, investment is included to figure out its impact on economic growth.

The real GDP per capita (US\$ 2010 constant price), life expectancy, resource rents, and government expenditure datasets were retrieved from the World Development Indicators (WDI) of the World Bank. The financial development indicators datasets were collected from the WDI excluding liquid liabilities gathered from the Structure and Financial Development of the World Bank. The investment (as \% GDP) is collected from the Penn World Table.

\section{B. Econometric model}

The theoretical reinforcement of the long-run impact of financial development on economic growth in selected MENA countries can be derived from the endogenous growth model. The work conducted by Pagano (1993) further developed the endogenous growth model to focus on the significance of the financial system in the process of economic growth. He adopts the AK model of Rebelo (1991) as an endogenous growth setting. In this model, it is assumed that only the capital $\left(K_{t}\right)$ is required in the production process, whereas the production function shows a constant return to scale. 


$$
Y=A K_{t}
$$

where $Y$ is the output, $A$ is total factor productivity, and $K$ is capital stock. Pagano's model also supposes that there is no population growth and capital depreciate at a rate of $\Theta$; thus, capital formation function is

$$
K_{t+1}=I_{t}+(1-\Theta) K_{t}
$$

where $K$ is capital formation and $\Theta$ is depreciation ratio. Only $\delta$ of the total savings $S$ is channeled through the financial system into investment:

$$
I_{t}=\delta S_{t}
$$

The steady-state growth rate $G$ is written as

$$
\begin{aligned}
& G=\frac{\left(K_{t+1}-K_{t}\right)}{K_{t}} \\
& G=\frac{\left.\left(I_{t}+(1-\Theta) K_{t}\right)-K_{t}\right)}{K_{t}} \\
& G=\left(\delta S_{t} / K_{t}-\Theta\right. \\
& G=A \delta S_{t}-\Theta
\end{aligned}
$$

From Eq. (7), it can be seen that the growth rate of steady state can be affected by the development of finance by saving, capital marginal product, depreciation ratios, and the fraction of savings going to investment, which reflects the financial sector's efficiency. Therefore, the growth rate $G$ will be affected by the financial deepening through the magnitude of savings channeled into investment. By assuming $\Theta$ as the constant rate of depreciation, the economic growth rate will depend on financial development. Thus Eq. (7) can be expressed by

$$
G=B_{0}+B_{1} S / Y+\varepsilon
$$

where S/Y represents total savings over the GDP that can be considered as a proxy for financial development (FD) factors. Therefore, Eq. (8) can be written as

$$
G=B_{0}+B_{1} F D+\varepsilon
$$


where $\mathrm{G}$ represents economic growth rate, $B_{0}$ represents coefficient of intercept, FD represents financial development, $B_{1}$ represents coefficients that reflect the impact of FD on economic growth, and lastly, $\varepsilon$ represents error term.

Therefore, based on the previous theoretical model and by following studies of Law et al. (2018), Levine and Zervos (1998) and King and Levine (1993a,1993b), the empirical model will be

$$
y_{i t}-y_{i t-1}=(1-\alpha) y_{i t-1}+\beta_{1} F D_{i t}+\beta_{2} X_{i t}+\eta i+\varepsilon_{i t}
$$

Equivalently, Eq. (10) may be written as

$$
y_{i t}=\alpha y_{i t-1}+\beta_{1} F D_{i t}+\beta_{2} X_{i t}+\eta i+\varepsilon_{i t}
$$

where $y$ refers to the real GDP per capita for a particular country $i$ at time $t$, FD indicates the level of financial development, $X$ reflects the vector of control variables that influence economic growth, $\eta_{i}$ is the unobserved country-specific effect, $\varepsilon_{i t}$ is the error term. All the variables have been transformed into logarithmic form. The conditional variables include variables repeatedly used in FD and economic growth literature, including natural resource rents, human capital, government expenditure, and investment.

The first model of this research was used to estimate the linear relation between finance and growth. Thus, we included the squared term of financial development $\left(\mathrm{FD}^{2}\right)$ in the model specification to apprehend the nonlinearities in financial development and economic growth. The advantage of polynomials is that they offer smooth functions when compared with threshold models that may involve sharp discrete adjustments. Consequently, the following specification model, including the squared term of FD, is

$$
y_{i t}=\alpha y_{i t-1}+\beta_{1} F D_{i t}+\beta_{2} F D_{i t}^{2}+\beta_{3} X_{i t}+\eta i+\varepsilon
$$

According to Eq. (12), if coefficients $\beta_{1}$ and $\beta_{2}$ are statistically significant with a negative and positive sign respectively, this implies the existence of a U-shape in the finance-growth nexus, whereas, if they are statistically significant with a positive and negative sign respectively, this indicates the presence of an inverted U-shape. To determine the optimal level of FD, we need to calculate the turning point from Eq. (12) as follows:

$$
\text { Optimal } F D(\%)=\frac{\partial y}{\partial F D}=\beta_{1}+2 \beta_{2} F D
$$




$$
\beta_{1}+2 \beta_{2} F D=0
$$

From Eq. (12.2), the value from equaling the slope to 0 is the turning point that indicates the optimal level of FD. To confirm that the relationship between finance-growth is not monotonic, as well as for the robustness of the results, we conducted the U-test by following Line and Mehlum (2010) under the joint hypothesis:

$$
\mathrm{H} 0:\left(a+b 2 F D_{\min } \leq 0\right) U\left(a+b 2 F D_{\max } \geq 0\right)
$$

Against the alternative hypothesis:

$$
\mathrm{HA}:\left(a+b 2 F D_{\min }>0\right) U\left(a+b 2 F D_{\max }<0\right)
$$

$F D_{\max }$ and $F D_{\min }$ represent the maximum and minimum values of financial development. According to the hypotheses, the non-significance of the null hypothesis means the existence of an inverted U-shape for finance-growth nexus. For the sufficiency condition of a quadratic interrelation, Lind and Mehlum (2010) highlighted the non-suitability of the standard econometric model for testing the combined null hypothesis with an increasing right side interval, whereas the left side of the correlation interval was decreasing or vice versa. Therefore, we proceeded with the U-test to confirm that our results reflect a non-linear relationship between FD and economic growth.

\section{Econometric methodology}

To achieve the objective of this paper, the applied econometric method is based on the pooled mean group (PMG) estimator developed by Pesaran et al. (1999). On the basis of this research, we may incorporate a dynamic heterogeneous panel regression into the error correction model by applying ARDL ( $p, q)$, where $q$ is the lag of the independent variables and $p$ is the lag of the dependent variables. The equation is as follows (Loayza \& Ranciere, 2006):

$$
\triangle G D P G_{i, t}=\sum_{j=1}^{p-1} \gamma_{j}^{i} \triangle G D P G_{i, t-j}+\sum_{j=0}^{q-1} \delta_{j}^{i} \Delta X_{i, t-j}+\varphi^{i}\left[G D P G_{i, t-1}-\left\{\beta_{0}^{i}+\beta_{1}^{i} X_{i, t-1}\right\}\right]+\varepsilon_{i t}
$$

where subscript $i$ is country index, subscript $t$ is time index, GDPG is the rate of GDP growth, $X$ reflects the independent variables involved in the model including FD, $\gamma$ is the short-run coefficient of the lagged dependent variables, $\delta$ is the short-run coefficient of the lagged independent variables, $\beta$ is the long-run coefficient, $\varphi$ is the coefficient of the speed of adjustment 
to the long-run equilibrium, and the term in the square brackets of Eq. (13) shows the long-run growth regression obtained from the following equation.

$$
G D P G_{i, t}=\beta_{0}^{i}+\beta_{1}^{i} X_{i, t}+\mu_{i, t} \quad \text { where } \mu_{i, t} \sim I(0)
$$

Equation (13) can be evaluated by three estimators: the PMG, the dynamic fixed effects (DFE), and the mean group (MG) model of Pesaran and Smith (1995). Pesaran and Shin (1999, chap. 4), Pesaran (1997), and Pesaran and Smith (1995) manifested ARDL as a new cointegration test in error correction form. Nevertheless, in this paper, we have emphasized the necessity to obtain an efficient and consistent estimation of the long-run correlation parameters.

Furthermore, the PMG is the appropriate approach for our dynamic panel analysis because it accommodates the equilibrium of the long-run and heterogeneous dynamic adjustment process. Based on Asteriou (2009), the PMG approach can estimate the model by integration of pooling and averaging of the variable coefficients where the cross-sectional units are smaller than the period of time. It allows the short-run coefficients, intercepts, and error variances to vary across countries, but it restricts the coefficients of the long-run to be the same. PMG helps to resolve heterogeneity bias common in traditional panel fixed and random effects estimations. The assumption of all traditional panel models is that across them, at least some parameters are similar. Moreover, Pesaran et al. (1999) highlighted that in long periods, the technique of traditional panel leads to an inconsistent outcomes inclusive panel generalized method of moment, and a false estimation of the parameter's average values in dynamic panel data model, with an exception if the coefficients of the slope are similar. Moreover, the PMG approach is valid when dealing with first-generation panels that assume spatial independence between the countries. Therefore, the cross-sectional dependence test was conducted, and results from Table A5 (see Appendix) confirmed that there is no cross-sectional dependence.

The different assumptions that governed the estimations of the long-run parameters for the MG and PMG estimators require a choice between two alternative specifications. In this regard, Pesaran et al. (1999) suggested using the Hausman test (1978). This test was conducted to figure out the existence of a significant difference between the three estimators. Thus, under the null hypothesis, the difference in the estimated coefficients was not significant; hence, the PMG estimator was more efficient. However, there is a significant difference if we reject the null and accept the alternative. In the case of the presence of outliers, the medium estimator contains a large variance. In this situation, the Hausman test will be negligible. The PMG estimator will be applied If the $p$-value is not significant at the $5 \%$ level. However, if there is a significant $p$-value, then either the DFE or MG estimator would be more relevant. 


\section{Estimation Results and Findings}

It is important to display the properties or characteristics of the datasets applied in the analysis before estimating our empirical model on the financial development-economic growth nexus. Table A1 (see Appendix) presents the descriptive statistics of all the variables used in our model with observations in yearly format. Table A2 (see Appendix) shows the pairwise correlation matrix for the key variables involved in our estimation of FD and economic growth. According to Table A2, the three measures of FD are positively associated with real GDP per capita (with coefficients of $0.18,0.26$, and 0.04 ). Moreover, the correlation between domestic credit and private sector credit is highly correlated at 0.86 . Conversely, the correlation between liquid liability and private sector and liquid liability and domestic credit are 0.68 and 0.66 , respectively. The results showed the correlation of the control variables that are used in most economic growth studies, i.e., government expenditure, human capital, resource rents, and investment have positive signs, whereas human capital exhibits the highest correlation with GDP per capita when compared with the correlation of resource rents.

Prior to running the three estimation approaches, we first needed to determine the stationarity of the variables. Thus, we applied the Im, Pesaran, and Shin $(1997,2003)$ test and Maddala-Wu, or MW (1999), test to verify the presence of unit roots in our panel dataset. We conducted these tests to ensure that no series exceeded the I(1) order of integration2). Test outcomes of the panel unit root are shown in Table A3 (see Appendix), for MW and IPS tests.

Results confirmed that most variables are non-stationary at the level and stationary at the first difference. Moreover, to confirm the long-run relationship between the dependent variable and the explanatory variables, Pedroni cointegration test was computed, and the results are presented in Table A4 (see Appendix). The results provide support to the presence of co-integrating relationships among the control variables. Further crucial element is the determination of the ARDL lag form by using congruous criterion3).

On the basis of the Schwartz Bayesian criterion, we imposed the $(1,0,0,0,0)$ lag structure for the rate of GDP growth, FD, government expenditure, life expectancy, investment, and resource rents in our model respectively.

\section{A. Linear model}

Since most of the variables of interest were stationary at the first difference, we proceeded with the dynamic estimation techniques. The model applied the explanatory variables, comprising

2) Asteriou and Monastiriotis (2004) indicated that when some variables were $I(2)$, the estimations were not consistent.

3) Because of the data limitation, imposing lag structure remains a possible option. Under the time constraint of not being long enough, previous studies such as Loayza and Ranciere (2006), Samargandi et al. (2015), and Pesaran et al. (1999) supported imposing a common lag structure across countries to exceed further the lag. 
the initial GDP per capita $\left(Y_{t-1}\right)$, private credit $(\mathrm{Pc})$, resource rents $(\mathrm{RR})$, government expenditures (GEXP), investment (INV), and life expectancy (Lifexp) to show its influence on the dependent variable, i.e., economic growth (GDP).

The empirical results of the linear model (Eq. (11)) are presented in Table 1, alongside the long- and short-run coefficients and error correction terms. Moreover, the Hausman test was used to measure the consistency and comparative efficiency.

As shown in Table 1, the error correction term (convergence coefficient) is significantly decreased when we applied the PMG approach comparing with the MG estimator. Additionally, DFE further reduced the speed of adjustment and standard errors due to the downward bias in the dynamic heterogeneous panel.

The values of the error correction coefficients for all three estimation techniques were negative and significant, which indicated the existence of cointegration (long run) among the considered variables. According to the PMG estimator, our findings determined that the private sector, as an indicator of FD in the linear model (Eq. (11)), had a positive sign in the long run and a significant influence on economic growth at level $1 \%$. But in the short run, the impact was insignificant and negative. Alternatively, the MG estimator suggested negative signs in the short run and positive signs in the long run, and both were not significant. However, the results of Samargandi et al. (2015) differed to our findings. Moreover, there was a significant negative sign for the private sector in the short and long runs. According to the DFE model, this concurred with previous research (Samargandi et al., 2015). There were multiplied by 100 to explicate them as percentages as the coefficients of the three variables of FD were lacking a natural logarithm ${ }^{4}$ ). For example, under the PMG estimator, the coefficient of the private sector in the long-run linear model (Eq. (11)) was .0031, which implied that economic growth would increase by $0.31 \%$ if private sector credit increased by $1 \%$.

Under the long run for DFE and PMG estimators, the coefficient of life expectancy was both significant and positive determinant of economic growth yet not significant for the $\mathrm{MG}$ approach. Conversely, the long- and short-run coefficients of government expenditure had significant negative signs under PMG and DFE approaches. Moreover, investment turns to be positive but significant only in the long run and under the PMG estimator. The differences that existed in the results from Table 1 are due to the diverse nature of the three estimation techniques applied.

Furthermore, over the selected MENA countries, long-run homogeneity restriction test was performed using the Hausman test. The outcomes once again displayed the effectiveness and consistency of the PMG estimator compared with alternative estimators. Since the null hypothesis is accepted by the Hausman test, the PMG estimator was the more efficient estimator.

4) Since Eq. (1) is a log-linear model, the coefficients lacking natural logarithm variables were multiplied by 100 to be converted to percentages. 
Table 1 indicates the evidence of negativity and significance of the error correction term in all three estimators. Based on the PMG outcomes, the magnitude of this disequilibrium correction was relatively moderate $(-0.323)$. The speed of adjustment/error correction term revealed that only a $32.3 \%$ adjustment/correction took place in 1 year.

Table 1. Outcomes of the linear finance-growth nexus

Dependent variable: economic growth $(N=11 ; \mathrm{T}=28$; sample period $=1987-2015)$

\begin{tabular}{|c|c|c|c|c|c|c|}
\hline & \multicolumn{2}{|c|}{ Pooled mean group } & \multicolumn{2}{|c|}{ Mean group } & \multicolumn{2}{|c|}{ Dynamic fixed effect } \\
\hline & Coef. & Std. error & Coef. & Std. error & Coef. & Std. error \\
\hline \multicolumn{7}{|l|}{ Long-run coefficients } \\
\hline LGEXP & $-0.0342 * *$ & 0.0136 & -0.4104 & 0.2634 & $-0.1712 * *$ & 0.0664 \\
\hline LLifexp & $3.1895 * * *$ & 0.1959 & 9.1171 & 9.4762 & $4.3736^{* * *}$ & 0.9245 \\
\hline LRRents & 0.0073 & 0.0109 & -0.0885 & 0.0743 & -0.0039 & 0.0592 \\
\hline LINV & $0.0088 * *$ & 0.0039 & -0.0088 & 0.0193 & -0.0149 & 0.0125 \\
\hline \multicolumn{7}{|l|}{ Financial development } \\
\hline $\mathrm{Pc}$ & $0.0031 * * *$ & 0.0002 & 0.0182 & 0.0174 & $-0.0022^{*}$ & 0.0013 \\
\hline Error correction coefficients & $-0.3225^{* *}$ & 0.0875 & $-0.5659 * * *$ & 0.0861 & $-0.2524 * * *$ & 0.0388 \\
\hline \multicolumn{7}{|l|}{ Short-run coefficients } \\
\hline$\triangle \mathrm{LGEXP}$ & $-0.1589 * * *$ & 0.0373 & $-0.1867 * * *$ & 0.0505 & $-0.0840^{*}$ & 0.0441 \\
\hline$\triangle$ Llifeexp & 15.9565 & 14.9332 & 40.7536 & 26.4333 & $4.4893 * *$ & 2.5068 \\
\hline$\triangle$ LRrents & $-0.0331 *$ & 0.0175 & -0.0485 & 0.0334 & -0.0260 & 0.0176 \\
\hline$\triangle \mathrm{LINV}$ & 0.0327 & 0.0238 & 0.0081 & 0.0211 & 0.0040 & 0.0277 \\
\hline \multicolumn{7}{|l|}{ Financial development } \\
\hline$\triangle \mathrm{Pc}$ & -0.0029 & 0.0019 & -0.0043 & 0.0028 & $-0.0045^{* * *}$ & 0.0008 \\
\hline Constant & $-1.4575 * * *$ & 0.4016 & 0.2165 & 3.9813 & $-2.1830 * *$ & 0.9883 \\
\hline Country & 11 & & 11 & & 11 & \\
\hline Observations & 308 & & 308 & & 308 & \\
\hline$p$-value (Hausman test) & & & $0.906^{\mathrm{a}}$ & & $0.979^{\mathrm{b}}$ & \\
\hline
\end{tabular}

(Note) $* * *$, and $* * *$ indicate the significance at the $10 \%, 5 \%$, and $1 \%$ levels. The estimations were conducted using the (xtpmg) routine in Stata. DFE, MG, and PMG estimators are all controlled for country and time effects. The first panel (LR) shows the long-run effects, whereas the second panel reports both the short-run effects (SR) and the speed of adjustment (EC).

a) By assuming the null hypothesis, the PMG is a more effective estimation than MG.

b) By assuming the null hypothesis, the PMG is a more effective estimation than DFE.

\section{B. Non-linear model}

Table 2 indicates the non-linear relationship between FD and economic growth (Eq. (12)). In terms of economic growth, the results suggest that the FD indicator and its squared term under the long run are significant determinants when using the PMG approach. Yet they were not significant under MG and DFE. The coefficients of private credit and its squared term were positive and negative respectively under PMG. These outcomes suggest that although 
FD promotes economic growth, after a certain level, it has a negative influence. Studies on economic growth and FD have mostly shown a corroboration of a concave relationship between these two. Ibrahim and Alagidede (2018), Law et al. (2018), Soedarmono et al. (2017), Law and Singh (2014), and Cecchetti and Karroubi (2012) concurred with our findings.

The results of the Hausman test confirmed that PMG was the most consistent and efficient estimator when compared with the DFE and MG estimators. The results of Arcand et al. (2012) and Samargandi et al. (2015) consolidated the "Too Much Finance" hypothesis.

Moreover, our findings confirmed that in the long run, the marginal effect of FD is positive up to a certain level, after which it becomes negative. Therefore, the turning point ${ }^{5)}$ regarding the measurement of FD by private sector credit and using the PMG estimator was around $64 \%$. Within a country where private sector credit is inferior or equal to the turning point (64\%), it will exercise a positive impact on economic growth.

Nonetheless, the negative influence above $64 \%$ will be noticeable. However, the value of the turning point in our sample was lower than that in previous studies. For example, Law et al. (2018), Law and Singh (2014), Cecchetti and Kharroubi (2012), and Arcand et al. (2012) found that the turning point of the private sector credit-to-GDP ratio ranged between $90 \%$ and $100 \%$. The differences of these turning points may have been due to the samples used in the respective studies; for example, our sample focused on MENA developing countries, whereas the samples of the previous studies covered both developed and developing countries. As the short-run effects were not significant, solely the long-run coefficients were employed to calculate the turning point.

The outcomes of our analysis suggest that finance might harm growth under certain conditions. Developed financial sector eases the resource-efficient allocation, decreases transaction costs and agency costs, and mobilizes savings which leads to rising economic growth and. Nevertheless, the input of the financial system will compete with the rest of the sectors, mainly skillful workers. Consequently, the vastness of the financial system unaccompanied by development in the profitable sectors of the country's economy might switch resources from other sectors of the economy to the financial system, which lower economic growth.

Regarding the control variables, there were mixed results under the three estimators. With PMG being the most consistent and efficient. Our discussion will emphasize the PMG estimation. Government expenditure was statistically significant determinant of economic growth in the short and long runs. This concurred with previous studies that found a negative effect of government expenditure on economic growth (Law \& Singh, 2014; Samargandi et al., 2015). This negative impact can happen because of the distortionary effects of consumption that governments usually have. It can be translated into present and/or future tax load on citizens.

5) The financial development turning point can be computed by setting the first difference in economic growth by respecting the private sector credit as a proxy of financial development equal to 0 . 
This scenario will harm investment and private spending (Barro, 1991, 1974). Within the MENA economy, if government investment absorbs a considerable proportion of public spending, our outcomes can be justified in a situation of shifting for an apparently more productive spending category. This may reduce the growth if its initial share is huge (Devarajan et al., 1996). In the same line, Ghosh and Gregoriou (2008) stated that similar scenarios may occur when optimizing governments do not perceive different sorts of public goods productivities and assign their spending disproportionately with their productivities.

In contrast, several studies have also found a positive sign for the effect of government spending on economic growth in the case of Canada, Australia, Spain, the UK, New Zealand, Finland, Sweden, and the US (Atesoglu, 1998; Attari \& Javed, 2013; Mallik \& Chowdhury, 2002). This suggests that the influence of government expenditure on economic growth is still inconclusive.

The coefficient of human capital was positive and significant in the long run but insignificant in the short run. However, the coefficient signs of RR are mixed and insignificant for both long and short runs, which indicates that economic growth from resource abundancy remains inconclusive. For instance, many scholars found a positive influence of natural RR like the pioneering work of $\mathrm{Wu}$ et al. (2018), arguing that a superior and abundant natural resource may protect growth sustainability in the economy of the region.

Conversely, other researchers found that an abundance of natural resources is detrimental. In the same line, Kim and Lin (2015) stated that natural resources might be problematic for developing countries. This happens typically because of government intervention, less sound money, worse property rights protection that are less open to international markets, and government corruption.

Researchers supported that enhancing financial systems is a crucial element as RR may affect economic growth (Shahbaz et al., 2018; Yuxiang \& Chen, 2011). This can happen because ameliorating financial systems raise trust among investors and the government. Therefore, promoting the expected positive impact of natural resources on economic growth (Law \& Moradbeigi, 2017).

Regarding investment, results showed that the coefficient of this variable is positive in short and long runs but not significant. 
Table 2. Results of the non-linear relationship between finance and growth. Dependent variable: economic growth $(N=11 ; \mathrm{T}=28$; sample period $=1987-2015)$

\begin{tabular}{|c|c|c|c|c|c|c|}
\hline & \multicolumn{2}{|c|}{ Pooled mean group } & \multicolumn{2}{|c|}{ Mean group } & \multicolumn{2}{|c|}{ Dynamic fixed effect } \\
\hline & Coef. & std. error & coef. & std. error & coef. & Std. error \\
\hline \multicolumn{7}{|l|}{ Long-run coefficients } \\
\hline LGEXP & $-0.0569 * * *$ & 0.0093 & -0.2885 & 0.2090 & $-0.1698 * *$ & 0.0673 \\
\hline LLifexp & $2.899 * * *$ & 0.1777 & $5.5740^{*}$ & 2.8071 & $4.2860 * * *$ & 0.9653 \\
\hline LRRents & 0.0055 & 0.0099 & -0.0559 & 0.0912 & -0.0135 & 0.0607 \\
\hline LINV & 0.0163 & 0.0202 & -0.0279 & 0.0852 & -0.0229 & 0.0920 \\
\hline \multicolumn{7}{|l|}{ Financial development } \\
\hline $\mathrm{Pc}$ & $0.0089^{* * *}$ & 0.0009 & -0.0015 & 0.0152 & -0.0013 & 0.0040 \\
\hline Pcsqr & $-0.00007^{* * *}$ & 0.00001 & 0.0002 & 0.0004 & -0.00002 & 0.00004 \\
\hline Error correction coefficients & $-0.3700 * * *$ & 0.0959 & $-0.5984 * * *$ & 0.0768 & $-0.2399 * * *$ & 0.0371 \\
\hline \multicolumn{7}{|l|}{ Short-run coefficients } \\
\hline$\triangle \mathrm{LGEXP}$ & $-0.1625 * * *$ & 0.0331 & $-0.2089 * * *$ & 0.0643 & $-0.0841^{* *}$ & 0.0420 \\
\hline$\triangle$ Llifeexp & 15.4197 & 13.6089 & $32.9703 *$ & 20.0013 & $5.3570^{* *}$ & 2.3980 \\
\hline$\triangle$ LRrents & $-0.0386^{*}$ & 0.0218 & -0.0329 & 0.0248 & $-0.0297 *$ & 0.0169 \\
\hline$\triangle \mathrm{LINV}$ & 0.0225 & 0.0157 & -0.0038 & 0.0321 & 0.0012 & 0.0278 \\
\hline \multicolumn{7}{|l|}{ Financial development } \\
\hline$\triangle \mathrm{Pc}$ & -0.0056 & 0.0057 & $-0.0111 *$ & 0.0058 & $-0.0133 * * *$ & 0.0018 \\
\hline$\Delta \mathrm{Pcsqr}$ & 0.00004 & 0.00005 & 0.00005 & 0.00004 & $0.0007 * * *$ & 0.00001 \\
\hline constant & $1.1330^{* * *}$ & 0.3081 & -8.0224 & 5.1446 & $-1.9980^{* *}$ & 0.9571 \\
\hline country & 11 & & 11 & & 11 & \\
\hline observations & 308 & & 308 & & 308 & \\
\hline$p$-value (Hausman test) & & & $0.926^{\mathrm{a}}$ & & $0.989^{\mathrm{b}}$ & \\
\hline
\end{tabular}

(Note) $* * *$, and $* * *$ indicate the significance at the $10 \%, 5 \%$, and $1 \%$ levels. The estimations were conducted using the (xtpmg) routine in Stata. DFE, MG, and PMG estimators are all controlled for country and time effects. The long-run effects are indicated by the first panel (LR). Both the speed of adjustment (EC) and short-run effects (SR) are reported in the second panel.

a) By assuming the null hypothesis, the PMG is a more effective estimation than MG.

b) By assuming the null hypothesis, the PMG is a more effective estimation than DFE.

\section{Robustness checks}

Robustness checks were conducted, where we re-estimated the non-linear model (Eq. (12)) by using two different proxies of FD (liquid liabilities and domestic credit). The full results are available in Table 3 and Table 4, and the robustness checks confirmed the validity of the model's specifications and the consistency of our findings. 
Table 3. Results of the mon-linear relationship between finance and growth. Dependent variable: economic growth $(N=11 ; \mathrm{T}=28$; sample period $=1987-2015)$

\begin{tabular}{|c|c|c|c|c|c|c|}
\hline & \multicolumn{2}{|c|}{ Pooled mean group } & \multicolumn{2}{|c|}{ Mean group } & \multicolumn{2}{|c|}{ Dynamic fixed effect } \\
\hline & Coef. & Std. error & Coef. & Std. error & Coef. & Std. error \\
\hline \multicolumn{7}{|l|}{ Long-run coefficients } \\
\hline LGEXP & $0.2880 * * *$ & 0.0853 & -0.2627 & 0.1799 & $-0.1365^{*}$ & 0.0729 \\
\hline LLifexp & $3.5972 * * *$ & 0.7373 & 1.0917 & 4.6694 & $3.6070 * * *$ & 1.0168 \\
\hline LRRents & -0.0026 & 0.0291 & -0.1080 & 0.1039 & 0.0283 & 0.0655 \\
\hline LINV & $0.0870 * *$ & 0.0412 & -0.0284 & 0.0764 & -0.0155 & 0.10006 \\
\hline \multicolumn{7}{|l|}{ Financial development } \\
\hline $\mathrm{DC}$ & $0.03336 * * *$ & 0.0070 & -0.0032 & 0.0163 & 0.0031 & 0.0055 \\
\hline Dcsqr & $-0.0004865^{* * *}$ & 0.0000973 & 0.00002 & 0.00019 & -0.00008 & 0.00006 \\
\hline Error correction coefficients & $-0.1014 * * *$ & 0.0348 & $-0.6407 * * *$ & 0.1044 & $-0.2328 * * *$ & 0.0389 \\
\hline \multicolumn{7}{|l|}{ Short-run coefficients } \\
\hline$\triangle \mathrm{LGEXP}$ & $-0.1217 * * *$ & 0.0418 & $-0.2386 * * *$ & 0.0787 & $-0.0934 * *$ & 0.0442 \\
\hline$\triangle$ Llifeexp & 0.4559 & 4.6739 & 17.9890 & 14.9378 & $3.8662 *$ & 2.4660 \\
\hline$\triangle$ Rrents & $-0.0452 *$ & 0.0274 & -0.0405 & 0.0489 & -0.0103 & 0.0175 \\
\hline$\triangle \mathrm{LINV}$ & -0.0083 & 0.0149 & -0.0748 & 0.0506 & 0.0046 & 0.0293 \\
\hline \multicolumn{7}{|l|}{ Financial development } \\
\hline$\triangle \mathrm{Dc}$ & -0.0127 & 0.0098 & -0.0082 & 0.0095 & $-0.0099 * * *$ & 0.0020 \\
\hline$\Delta \mathrm{Dcsqr}$ & 0.00015 & 0.00014 & 0.00007 & 0.00009 & $0.00006 * * *$ & 0.00002 \\
\hline constant & $-0.8098 * * *$ & 0.2979 & 4.9741 & 12.9547 & -1.3214 & 0.9867 \\
\hline country & 11 & & 11 & & 11 & \\
\hline observations & 308 & & 308 & & 308 & \\
\hline$p$-value (Hausman test) & & & $0.7303^{\mathrm{a}}$ & & $0.989^{\mathrm{b}}$ & \\
\hline
\end{tabular}

(Note) $*, * *$, and $* * *$ indicate the significance at the $10 \%, 5 \%$, and $1 \%$ levels. The estimations were conducted using the (xtpmg) routine in Stata. DFE, MG, and PMG estimators are all controlled for country and time effects. The long-run effects are indicated by the first panel (LR). Both the speed of adjustment (EC) and short-run effects (SR) are reported in the second panel.

a) By assuming the null hypothesis, the PMG is a more effective estimation than MG.

b) By assuming the null hypothesis, the PMG is a more effective estimation than DFE. 
Table 4. Results of the non-linear relationship between finance and growth. Dependent variable: economic growth $(N=11 ; \mathrm{T}=28$; sample period $=1987-2015)$

\begin{tabular}{|c|c|c|c|c|c|c|}
\hline & \multicolumn{2}{|c|}{ Pooled mean group } & \multicolumn{2}{|c|}{ Mean group } & \multicolumn{2}{|c|}{ Dynamic fixed effect } \\
\hline & Coef. & Std. error & Coef. & Std. error & Coef. & Std. error \\
\hline \multicolumn{7}{|l|}{ Long-run coefficients } \\
\hline LGEXP & 0.0478 & 0.0328 & -0.0689 & 0.0819 & -0.0455 & 0.0764 \\
\hline LLifexp & $2.6060 * * *$ & 0.2559 & $3.9766^{* *}$ & 1.7520 & $4.5073 * * *$ & 1.0166 \\
\hline LRRents & 0.0125 & 0.0180 & -0.0032 & 0.0323 & -0.0060 & 0.0669 \\
\hline IINV & $0.0002 * * *$ & 0.00006 & 0.0054 & 0.0075 & -0.0002 & 0.0144 \\
\hline \multicolumn{7}{|l|}{ Financial development } \\
\hline LL & $0.00563 * * *$ & 0.00098 & 0.002343 & 0.0057 & $-0.0049^{*}$ & 0.0027 \\
\hline LLsqr & $-0.00003^{* * *}$ & 0.0000067 & -0.000031 & 0.000047 & 0.000011 & 0.000012 \\
\hline Error correction coefficients & $-0.2146^{* * *}$ & 0.0687 & $-0.7892^{* * *}$ & 0.1304 & $-0.2003 * * *$ & 0.0345 \\
\hline \multicolumn{7}{|l|}{ Short-run coefficients } \\
\hline$\triangle$ LGEXP & $-0.0875^{* * *}$ & 0.0256 & $-0.1293^{* * *}$ & 0.0496 & 0.0218 & 0.0407 \\
\hline$\triangle$ Llifeexp & 23.6989 & 22.8490 & 30.5957 & 23.8254 & $4.9862 * *$ & 2.1670 \\
\hline$\triangle$ Rrents & -0.0211 & 0.0150 & $-0.0272 *$ & 0.0157 & $-0.0338^{* *}$ & 0.0155 \\
\hline$\triangle \mathrm{LINV}$ & 0.0111 & 0.0196 & -0.0050 & 0.0255 & -0.0257 & 0.0254 \\
\hline \multicolumn{7}{|l|}{ Financial development } \\
\hline$\triangle \mathrm{LL}$ & -0.0039 & 0.0035 & -0.0044 & 0.0029 & $-0.0078^{* * *}$ & 0.0009 \\
\hline$\triangle \mathrm{LLsqr}$ & 0.000011 & 0.00003 & 0.000018 & 0.000022 & $0.000018 * * *$ & 0.0000365 \\
\hline constant & $-0.5746^{* * *}$ & 0.2034 & -4.7619 & 5.6126 & $-1.9053^{* *}$ & 0.8422 \\
\hline country & 11 & & 11 & & 11 & \\
\hline observations & 308 & & 308 & & 308 & \\
\hline$p$-value (Hausman test) & & & $0.997^{\mathrm{a}}$ & & $0.999^{\mathrm{b}}$ & \\
\hline
\end{tabular}

(Note) $*, * *$, and $* * *$ indicate the significance at the $10 \%, 5 \%$, and $1 \%$ levels. The estimations were conducted using the (xtpmg) routine in Stata. DFE, MG, and PMG estimators are all controlled for country and time effects. The long-run effects are indicated by the first panel (LR). Both the speed of adjustment (EC) and short-run effects (SR) are reported in the second panel.

a) By assuming the null hypothesis, the PMG is a more effective estimation than MG.

b) By assuming the null hypothesis, the PMG is a more effective estimation than DFE.

We conducted another test to confirm the robustness in Table 3. To validate the non-monotonic relationship between finance and growth, we conducted the U-test of Lind and Mehlum (2010). Table 4 indicates the results of this test for the three proxies. Our results have not changed, although the turning points of the non-monotonic relation between finance and growth of each proxy were slightly different. For instance, with private credit, results of the FD lower bound slope $(0.018)$ are positive. At the same time, the upper bound slope $(-0.0143)$ is negative. As both are statistically significant; thus, the null hypothesis of a U-shaped relationship is rejected. 
Table 5. Results of the lind-mehlum test

\begin{tabular}{|c|c|c|c|c|c|c|}
\hline & \multicolumn{2}{|c|}{$\mathrm{FD}=$ private sector } & \multicolumn{2}{|c|}{$\mathrm{FD}=$ domestic credit } & \multicolumn{2}{|c|}{$\mathrm{FD}=$ liquid liabilities } \\
\hline & Lower bound & Upper bound & Lower bound & Upper bound & Lower bound & Upper bound \\
\hline Interval & 4.14 & 114.08 & 3.09 & 98.51 & 8.27 & 228.16 \\
\hline Slope & 0.0180912 & -0.0143505 & 0.0195683 & -0.0190605 & 0.0098403 & -0.0154541 \\
\hline t-value & 2.819327 & -1.554832 & 2.438883 & -1.668063 & 2.881354 & -3.111765 \\
\hline$p>|\mathrm{t}|$ & 0.0025601 & 0.0604999 & 0.007645 & 0.0481533 & 0.0021171 & 0.0010159 \\
\hline
\end{tabular}

\section{Conclusion}

This study investigated the long-run impact of FD on economic growth in select MENA countries over 1987-2015 by using the PMG, MG, and DFE. Our findings regarding the linear relationship between finance and growth, under PMG, were positively correlated in the long-run, whereas the short-run had a negative sign. Our findings were in agreement with Loayza and Ranciere (2006) outcomes and partially concurred with Samargandi et al. (2015).

Because of mixed results, we investigated the possibility of a non-monotonic impact of finance-growth nexus by introducing the quadratic polynomial of FD in the model. As highlighted by the significant positive coefficient attributed to FD and the negative coefficient attributed to its squared value, our results demonstrated the non-linearity of this association and validated the inverse U-shaped for finance-growth nexus. Our findings were similar to those of Samargandi et al. (2015), Law and Singh (2014), and Arcand et al. (2012). The findings were also confirmed by performing the U-test of Lind and Mehlum (2010). Furthermore, the detected finance-growth nexus was found to be robust for three indicators' measurements of FD and additional explanatory variables.

According to these findings, additional finance may not always be better in the case of the MENA region, as it tends to harm growth. For more productive activities and higher-level growth, knowing the efficient channeling of financial resources and optimal financial level for growth is crucial.

The outcomes of our study are important to policymakers, in terms of optimizing the necessary and limit of FD to ensure maximum benefit for the whole economy through the banking sector. Therefore, policymakers should focus more on improving the intermediating function of the financial sector rather than increasing its size. Instead of promoting and expanding finance to foster economic growth, policymakers should establish measures for strengthening the quality, as well as using the appropriate type, of finance. Moreover, if the finance point has been reached (64\%), policymakers should focus on other growth-enhancing strategies.

Future research could shed more light on this relationship by using other proxies for FD. 
For instance, an equity market indicator could be used because equity finance plays a vital role in channeling funds that firms increasingly depend upon. Therefore, examining if the development of stock market also implies a non-monotonic impact on growth may be relevant. Moreover, MENA incorporates various levels of FD within its constituent countries; thus, investigating the non-linear relationship found in this study in the individual countries may be of interest.

\section{References}

Abu-Bader, S., \& Abu-Qarn, A. S. (2008). Financial development and economic growth: The Egyptian experience. Journal of Policy Modelling, 30, 887-898.

Al-Tamimi, H. A. H., Al-Awad, M., \& Charif, H. A. (2002). Finance and growth: Evidence from some Arab countries. Journal of Transnational Management Development, 7, 3-18.

Al-Avad, M., \& Harb, N. (2005). Financial deepening and economic growth in the Middle East. Applied Financial Economics, 15, 1041-1051

Apergis, N., \& Payne, J. E. (2014). The oil curse, institutional quality, and growth in MENA countries: Evidence from time-varying cointegration. Energy Economics, 46, 1-9.

Arcand, J.-L., Berkes, E., \& Panizza, U. (2012). Too much finance? IMF Working Paper. WP/12/161. Washington: D.C.

Asteriou, D. (2009). Foreign aid and economic growth: New evidence from a panel data approach for five South Asian countries. Journal of Policy Modelling, 31, 155-161.

Asteriou, D., \& Monastiriotis, V. (2004). What do unions do at the large scale? Macro-economic evidence from a panel of OECD countries. Journal of Applied Economics, 7, 27-46.

Atesoglu, H. S. (1998). Inflation and real income. Journal of Post Keynesian Economics, 20, 487.

Attaria, M. I. J., \& Javed, A. Y. (2013). Inflation, economic growth and government Expenditure of Pakistan: 1980-2010. Procedia Economics and Finance, 5, 58-67.

Barro, R. J. (1974). Are government bonds net wealth? Journal of Political Economy, 82, 1095-1117.

Barro, R. J. (1991). Economic growth in a cross section of countries. Quarterly Journal of Economics, 106, 407-443.

Bhattacharyya, S., \& Hodler, R. (2014). Do natural resource revenues hinder financial development?: The role of political institutions. World Development, 57, 101-113.

Beck, T., Levine, R., \& Loayza, N. (2000). Finance and the sources of growth. Journal of Financial Economics, 58, 261-300.

Beck, T., Degryse, H., \& Kneer, C. (2014). Is more finance better?: Disentangling intermediation and size effects of financial systems. Journal of Financial Stability, 10, 50-64.

Ben Naceur, S., \& Ghazouani, S. (2007). Stocks markets, banks, and economic growth: Empirical evidence from the MENA region. Research in International Business and Finance, 21, 297-315.

Ben Naceur, S., Ghazouani, S., \& Omran, M. (2008). Does stock market liberalization spur financial 
and economic development in the MENA region? Journal of Comparative Economics, 36, 673-693. Bencivenga, V. R., \& Smith, B. D. (1991). Financial intermediation and endogenous growth. The Review of Economic Studies, 58, 195-209.

Boulila, G., \& Trabelsi, M. (2004). The causality issues in the finance and growth nexus: Empirical evidence from Middle East and North African countries. Review of Middle East Economics and Finance, 2, 123-138.

Cecchetti, S. G., \& Kharroubi, E. (2012). Reassessing the impact of finance on growth. Bank of International Settlements. Working Paper, No. 381.

Creane, S., Goyal, R., Mobarak, A. M., \& Sab, R. (2004). Evaluating financial sector development in the Middle East and North Africa: New methodology and some new results, topics in Middle Eastern and North African economies. http://www.luc.edu/orgs/meea/volume6/Creane.pdf (12.11.2008).

Bencivenga, V. R., \& Smith, B. D. (1991). Financial intermediation and endogenous growth. The Review of Economic Studies, 58, 195-209.

Devarajan S., Swaroop, V., \& Zou, H. (1996). The composition of public expenditure and economic growth. Journal of Monetary Economics, 37, 313-344.

Gazdar, K., \& Cherif, M. (2015). Institutions and the finance-growth nexus: Empirical evidence from MENA countries. Borsa Istanbul Review, 3, 137-160.

Goldsmith, R. W. (1969). Financial structure and development, New Haven, CT: Yale University Press.

Ghosh, S., \& Gregoriou, A. (2008). The composition of government spending and growth: Is current or capital spending better? Oxford Economic Papers, 60, 484-516.

Graff Zivin, J., \& M. Neidell. (2013). Environment, Health, and Human Capital. NBER Working paper 18935. Cambridge, MA: National Bureau of Economic Research.

Greenwood, J., \& Jovanovic, B. (1990). Financial development, growth, and the distribution of income, Department of Economics, Social Science Centre, University of Western Ontario.

Hausman, J. A. (1978). Specification tests in econometrics. Econometrica, 46, 1251-1271.

Ibrahim, M., \& Alagidede, P. (2018). Nonlinearities in financial development-economic growth nexus: Evidence from sub-Saharan Africa. Research in International Business and Finance, 46, 95-104.

Im, K. S., Pesaran, M. H., \& Shin, Y. (2003). Testing for unit roots in heterogeneous panels. Journal of Econometrics, 115, 53-74.

Kar, M., Nazlığlu, Ş., \& Ağır, H. (2011). Financial development and economic growth nexus in the MENA countries: Bootstrap panel granger causality analysis. Economic Modelling, 28, 685-693.

Kim, D. H., \& Lin, S. C. (2015). Natural resources and economic development: New panel evidence. Environmental \& Resource Economics, 1-29.

King, R. G., \& Levine, R. (1993a). Finance and growth: Schumpeter might be right. The Quarterly Journal of Economics, 108, 717-738.

King, R. G., \& Levine, R. (1993b). Finance, entrepreneurship, and growth: Theory and evidence. Journal of Monetary Economics, 32, 513.

Law, S. H., \& Singh, N. (2014). Does too much finance harm economic growth? Journal of Banking and Finance, 41, 36-44.

Law, S. H., \& Moradbeigi, M. (2017). Financial development and oil resource abundance-growth relations: 
Evidence from panel data. Environment Science and Pollution Research, 24, 22458-22475.

Law, S. H., Naseem, N. A. M., \& Kutan, A. M. (2018). The role of institutions in finance curse: Evidence from international data. Journal of Comparative Economics, 46, 174-191.

Levine, R., Loayza, N., \& Beck, T. (2000). Financial intermediation and growth: Causality and causes. Journal of Monetary Economics, 46, 31-71.

Lind, J. T., \& Mehlum, H. (2010). With or without U? The appropriate test for a U-shaped relationship. Oxford Bulletin of Economics and Statistics, 72, 109-118.

Levine, R., \& Zervos, S. (1998). Capital control liberalization and stock market development. World Development, 26, 1169-1183.

Loayza, N. V., \& Rancie're, R. (2006). Financial development, financial fragility, and growth. Journal of Money, Credit and Banking, 38, 1051-1076.

Lucas, R. (1988). On the mechanics of economic development. Journal of Monetary Economics 22, 2-42.

Maddala, G. S., \& Wu, S. (1999). A comparative study of unit root tests with panel data and new simple test. Oxford Bulletin of Economics and Statistics, 61, 631-652.

Majbouri, M. (2015). Calculating the income counterfactual for oil producing countries of the MENA region. Resource Policy, 44, 47-56.

Mallik, G., \& Chowdhury, A. (2002). Inflation, government expenditure and real income in the long run. Journal of Economic Studies, 29, 240.

McKinnon, R. I. (1973). Money and capital in economic development, Washington: Brookings Institution Press.

Patrick, H. T. (1966). Financial development and economic growth in underdeveloped countries. Economic Development and Cultural Change, 14, 174-189.

Pagano, M. (1993). Financial markets and growth: An overview. European Economic Review 37, 613-622.

Pesaran, M. H. (1997). The role of economic theory in modelling the long-run. The Economic Journal, 107, 178-191.

Pesaran, M. H., \& Shin, Y. (1999). An autoregressive distributed lag modelling approach to cointegration analysis. In Econometrics and Economic Theory in 20th Century: The Ranger Frisch Centennial Symposium, edited by Storm, S., Cambridge University Press, Cambridge.

Pesaran, M. H., Shin, Y., \& Smith, R. P. (1999). Pooled mean group estimation of dynamic heterogeneous panels. Journal of the American Statistical Association, 94, 621-634.

Pesaran, M. H., \& Smith, R. (1995). Estimating long-run relationships from dynamic heterogeneous panels. Journal of Econometrics, 68, 79-113.

Rajan, R. G., \& Zingales, L. (2003). The great reversals: The politics of financial development in the twentieth century. Journal of Financial Economics, 69, 5-50.

Rajan, R. G., \& Zingales, L. (1998). Financial dependence and growth. The American Economic Review, 88, 559-586.

Rioja, F., \& Valev, N. (2004). Does one size fit all?: A re-examination of the finance and growth relationship. Journal of Development Economics, 74, 429-447.

Robinson, J. (1952). The generalization of the general theory. In The rate of interest and other essays, London: Macmillan.

Romer, P. M. (1986). Increasing returns and long run growth. Journal of Political Economy, 94(5), 1002-1037. 
Samargandi, N., Fidrmuc, J., \& Ghosh, S. (2014). Financial development and economic growth in an oil-rich economy: The case of Saudi Arabia. Economic Modelling, 43, 267-278.

Schumpeter J. (2011). Theory of economic development: An inquiry into profits capital, credit, interest, and the business cycle. Publishing House of "Kyiv-Mohyla Academy" (In Ukrainian).

Schumpeter, J. (1912). Theorie der Wirtshaftlichen Entwicklung-English translation: The Theory of Economic Development, Translated by R. Opie, 1934, Cambridge, Mass.

Schumpeter, J. A., \& Opie, R. (1934). The theory of economic development: An inquiry into profits, capital, credit, interest, and the business cycle. Cambridge, Mass.: Harvard University Press.

Shahbaz, M., Naeem, M., Ahad, M., \& Tahir, I. (2018). Is natural resource abundance a stimulus for financial development in the USA? Resource Policy, 55, 223-232.

Shaw, E. S. (1973). Financial deepening in economic development. New York: Oxford University Press.

Soedarmono, W., Hasan, I., \& Arsyad, N. (2017). Non-linearity in the finance-growth nexus: Evidence from Indonesia. International Economics, 150, 19-35.

Yuxiang, K., \& Chen, Z. (2011). Resource abundance and financial development: evidence from China. Resource Policy, 36, 72-79.

W, S., Li, L., \& Li, S. (2018). Natural resource abundance, natural resource-oriented industry dependence, and economic growth: Evidence from the provincial level in China. Resources, Conservation \& Recycling, 139, 163-171. 


\section{Appendix}

Figure A1. Graphical representation for finance-growth nexus in MENA region

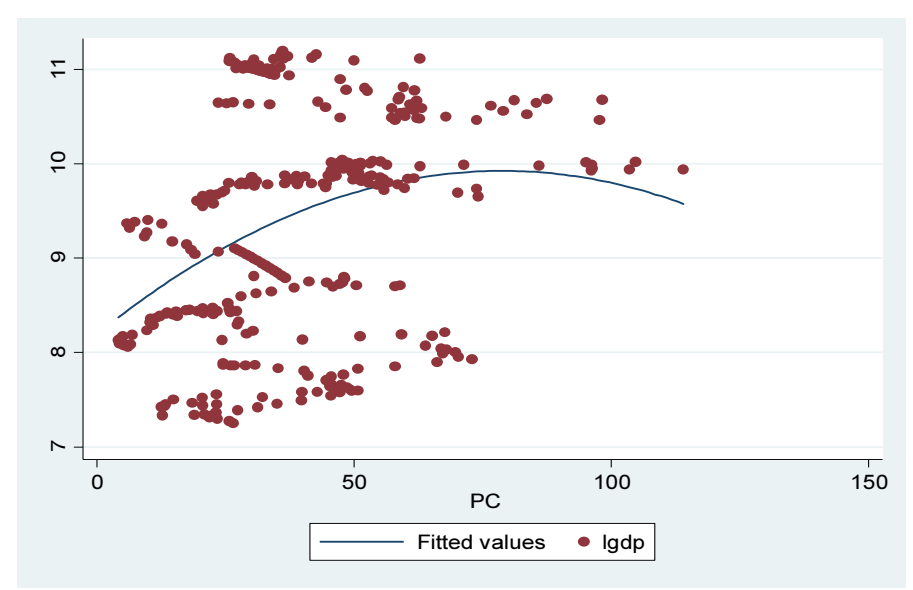

(Source) Author by using data from World Bank Indicators

Table A1. Descriptive statistics

\begin{tabular}{llccccc}
\hline \multicolumn{1}{c}{ Variable } & \multicolumn{1}{c}{ Unit of measurement } & Obs & Mean & Std. dev. & Min & Max \\
\hline Real GDP per capita & US\$ 2010 Constant Price & 319 & 21569.28 & 20971.86 & 1408.542 & 72670.96 \\
Initial income & US\$ 2010 Constant Price & 308 & 21603.57 & 21027.48 & 1408.54 & 72670.96 \\
Financial development & & & & & & \\
Private Sector Credit & \% of GDP & 319 & 39.55 & 20.33 & 4.14 & 114.08 \\
Liquide Liabilities & \% of GDP & 319 & 68.33 & 37.63 & 8.27 & 228.16 \\
Domestic Credit & \% of GDP & 319 & 36.74 & 18.09 & 3.09 & 98.51 \\
& & & & & & \\
Government Expenditure & \% of GDP & 319 & 19.30 & 8.37 & 1 & 76.22 \\
Life expectancy (HC) & Number of years & 319 & 71.90 & 3.54 & 58.68 & 78.04 \\
Resource rents & \% of GDP & 319 & 22.62 & 15.98 & 0.002 & 85.74 \\
Investment & \% of GDP & 319 & 7.89 & 2.30 & 1.83 & 11.5 \\
\hline
\end{tabular}

(Note) All statistics are based on the original data values. 
Table A2. Correlations

\begin{tabular}{|c|c|c|c|c|c|c|c|c|c|}
\hline & RGDP & INITIAL & $\mathrm{PC}$ & LL & $\mathrm{DC}$ & RRENTS & GEXP & $\mathrm{HC}$ & INV \\
\hline RGDP & $1 * * *$ & & & & & & & & \\
\hline INITIAL & $0.997 * * *$ & $1 * * *$ & & & & & & & \\
\hline PC & $0.176^{* * *}$ & $0.184 * * *$ & $1 * * *$ & & & & & & \\
\hline LL & 0.041 & 0.051 & $0.684 * * *$ & $1 * * *$ & & & & & \\
\hline DC & $0.258 * * *$ & $0.267 * * *$ & $0.860 * * *$ & $0.657 * * *$ & $1^{* * *}$ & & & & \\
\hline RRENTS & $0.326^{* * *}$ & $0.322^{* * *}$ & -0.065 & $-0.371 * * *$ & -0.077 & $1 * * *$ & & & \\
\hline GEXP & $0.330 * * *$ & $0.330 * * *$ & $0.149 * * *$ & $0.010 * * *$ & 0.087 & $0.103 *$ & $1 * * *$ & & \\
\hline $\mathrm{HC}$ & $0.596^{* * *}$ & $0.597 * * *$ & $0.400 * * *$ & $0.195 * * *$ & $0.462 * * *$ & 0.269 & $0.186^{* * *}$ & $1 * * *$ & \\
\hline INV & $0.316^{* * *}$ & $0.318 * * *$ & $0.361 * * *$ & $0.094 *$ & $0.355^{* * *}$ & $0.261 * * *$ & -0.041 & $0.603 * * *$ & $1 * * *$ \\
\hline
\end{tabular}

(Notes) $1-$ RGDP $=$ real GDP per capita; Initial = the initial income; PC $=$ credit from private sector; $\mathrm{LL}=$ liquid liabilities; DC = domestic credit; GEXP = government expenditure; HC = human capital (life expectancy); RRENTS $=$ resource rents; INV $=$ investment

$2-*, * *$, and $* * *$ indicates significance at $10 \%, 5 \%$, and $1 \%$ levels.

Table A3. Panel unit root test

\begin{tabular}{|c|c|c|c|c|c|c|c|c|}
\hline & \multicolumn{4}{|c|}{ MW(Fisher-ADF) } & \multicolumn{4}{|c|}{ IPS } \\
\hline & \multicolumn{2}{|c|}{ Level } & \multicolumn{2}{|c|}{ First difference } & \multicolumn{2}{|c|}{ Level } & \multicolumn{2}{|c|}{ First difference } \\
\hline & Constant & $\begin{array}{c}\text { Constant } \\
+ \\
\text { Trend }\end{array}$ & Constant & $\begin{array}{c}\text { Constant } \\
+ \\
\text { Trend }\end{array}$ & Constant & $\begin{array}{c}\text { Constant } \\
+ \\
\text { Trend }\end{array}$ & Constant & $\begin{array}{c}\text { Constant } \\
+ \\
\text { Trend }\end{array}$ \\
\hline LY & $\begin{array}{c}20.55 \\
(1)\end{array}$ & $\begin{array}{c}17.59 \\
(1)\end{array}$ & $\begin{array}{c}117.55^{* * *} \\
\text { (1) }\end{array}$ & $\begin{array}{c}99.35 * * * \\
(1)\end{array}$ & $\begin{array}{l}0.80 \\
(1)\end{array}$ & $\begin{array}{c}0.31 \\
(1)\end{array}$ & $\begin{array}{c}-7.01 * * * \\
(1)\end{array}$ & $\begin{array}{c}-5.65^{* * *} \\
(1)\end{array}$ \\
\hline$L Y_{t-1}$ & $\begin{array}{c}20.67 \\
(1)\end{array}$ & $\begin{array}{c}20.68 \\
(1)\end{array}$ & $\begin{array}{c}120.39 * * * \\
\text { (1) }\end{array}$ & $\begin{array}{c}98.40 * * * \\
\text { (1) }\end{array}$ & $\begin{array}{c}0.86 \\
(1)\end{array}$ & $\begin{array}{c}-0.13 \\
(1)\end{array}$ & $\begin{array}{c}-6.95^{* * *} \\
(1)\end{array}$ & $\begin{array}{c}-5.40^{* * *} \\
(1)\end{array}$ \\
\hline $\mathrm{PC}$ & $\begin{array}{c}18.80 \\
(1)\end{array}$ & $\begin{array}{c}28.67 \\
(1)\end{array}$ & $\begin{array}{c}60.98 * * * \\
(1)\end{array}$ & $\begin{array}{c}52.34 * * * \\
(1)\end{array}$ & $\begin{array}{l}0.46 \\
(1)\end{array}$ & $\begin{array}{l}0.87 \\
(1)\end{array}$ & $\begin{array}{c}-3.21 * * \\
(1)\end{array}$ & $\begin{array}{c}-2.46 * * \\
(1)\end{array}$ \\
\hline DC & $\begin{array}{c}18.98 \\
(1)\end{array}$ & $\begin{array}{c}26.52 \\
(1)\end{array}$ & $\begin{array}{c}71.10^{* * * *} \\
\text { (1) }\end{array}$ & $\begin{array}{c}57.46 * * * \\
(1)\end{array}$ & $\begin{array}{l}1.51 \\
(2)\end{array}$ & $\begin{array}{c}0.29 \\
(1)\end{array}$ & $\begin{array}{c}-4.77 * * * \\
(1)\end{array}$ & $\begin{array}{c}-3.71 * * * \\
(1)\end{array}$ \\
\hline LL & $\begin{array}{c}23.99 \\
(1)\end{array}$ & $\begin{array}{c}19.67 \\
(1)\end{array}$ & $\begin{array}{c}88.45^{* * *} \\
\text { (1) }\end{array}$ & $\begin{array}{c}75.33 * * * \\
(1)\end{array}$ & $\begin{array}{l}1.09 \\
(1)\end{array}$ & $\begin{array}{l}1.16 \\
(1)\end{array}$ & $\begin{array}{c}-5.27 * * * \\
(1)\end{array}$ & $\begin{array}{c}-4.51^{* * *} \\
(1)\end{array}$ \\
\hline LRrents & $\begin{array}{c}22.58 \\
(2)\end{array}$ & $\begin{array}{c}20.32 \\
(2)\end{array}$ & $\begin{array}{c}85.54 * * * \\
\text { (2) }\end{array}$ & $\begin{array}{c}55.18^{* * * *} \\
(2)\end{array}$ & $\begin{array}{c}-1.11 \\
(2)\end{array}$ & $\begin{array}{l}0.08 \\
(2)\end{array}$ & $\begin{array}{c}-5.78^{* * *} \\
(1)\end{array}$ & $\begin{array}{c}-3.70^{* * *} \\
(1)\end{array}$ \\
\hline LGEXP & $\begin{array}{c}28.53 \\
(2)\end{array}$ & $\begin{array}{c}16.68 \\
(3)\end{array}$ & $\begin{array}{c}69.86^{* * * *} \\
(2)\end{array}$ & $\begin{array}{c}43.25^{* *} \\
\text { (1) }\end{array}$ & $\begin{array}{c}-0.44 \\
(3)\end{array}$ & $\begin{array}{l}1.71 \\
(3)\end{array}$ & $\begin{array}{c}-4.32^{* * *} \\
\text { (3) }\end{array}$ & $\begin{array}{c}-2.73^{* *} \\
(3)\end{array}$ \\
\hline LLifeexp & $\begin{array}{l}8.03 \\
(1)\end{array}$ & $\begin{array}{c}22.95 \\
(2)\end{array}$ & $\begin{array}{c}34.53^{* *} \\
(2)\end{array}$ & $\begin{array}{c}78.48^{* * * *} \\
(2)\end{array}$ & $\begin{array}{c}-0.12 \\
(2)\end{array}$ & $\begin{array}{c}0.99 \\
(2)\end{array}$ & $\begin{array}{c}-2.39 * * \\
(2)\end{array}$ & $\begin{array}{c}-4.52 * * \\
(2)\end{array}$ \\
\hline INV & $\begin{array}{c}25.76 \\
(3)\end{array}$ & $\begin{array}{c}11.38 \\
(3)\end{array}$ & $\begin{array}{c}87.59 * * * \\
\text { (2) }\end{array}$ & $\begin{array}{c}64.66^{* * *} \\
(2)\end{array}$ & $\begin{array}{c}-0.24 \\
(1)\end{array}$ & $\begin{array}{c}-0.23 \\
(1)\end{array}$ & $\begin{array}{c}-11.38 * * * \\
\text { (1) }\end{array}$ & $\begin{array}{c}-10.13^{* * *} \\
\text { (1) }\end{array}$ \\
\hline
\end{tabular}

(Notes) 1- The asterisks ***,**, and * indicate the rejection of the unit root null hypothesis at the $1 \%, 5 \%$, and $10 \%$ significance levels, respectively.

2- Optimal lag length is provided between parentheses.

3- The likelihoods for the MW (Fisher-ADF) test were calculated by applying an asymptotic chi-square dispersion. There is an assumption of asymptotic normality when using the IPS test. 
Table A4. Pedroni cointegration test

\begin{tabular}{lccc}
\hline \multicolumn{4}{c}{ Constant + Trend } \\
\hline & FD = private credit & FD $=$ domestic credit & FD = liquid liabilities \\
\hline Panel v-statistic & 0.905 & 1.322 & 0.878 \\
Panel rho-statistic & -0.974 & -0.882 & -0.985 \\
Panel PP-statistic & $-5.181^{* * *}$ & $-5.121^{* * *}$ & $-5.379^{* * *}$ \\
Panel ADF-statistic & $-1.621^{*}$ & $-1.951^{* *}$ & $-1.416^{*}$ \\
Group rho-statistic & -0.082 & 0.236 & 0.291 \\
Group PP-statistic & $-7.248^{* * *}$ & $-7.189^{* * *}$ & $-7.280^{* * *}$ \\
Group ADF-statistic & $-2.229^{* * *}$ & $-2.819^{* * *}$ & $-2.483^{* * *}$
\end{tabular}

(Notes) $1-*, * *$, and *** indicate significance at $10 \%, 5 \%$, and $1 \%$ levels.

2- Null hypothesis is no cointegration.

3- The critical value for one side test is -1.64 . Thus, a large negative value $(k<-1.64)$ implies the rejection of null hypothesis (no cointegration). However, the critical value of V-test is 1.64; hence, to reject the null hypothesis, it requires values greater than 1.64.

Table A5. Cross-sectional dependence test

\begin{tabular}{lcccccc}
\hline \multicolumn{1}{c}{ Gdp } & Coef & Std. err. & $\mathrm{t}$ & $p>|\mathrm{t}|$ & \multicolumn{2}{c}{$[95 \%$ Conf. interval] } \\
\hline gdpt1 & .9133667 & .0245608 & 37.19 & 0.000 & .8650275 & .961706 \\
$\mathrm{pc}$ & -16.82208 & 6.241208 & -2.70 & 0.007 & -29.1057 & -4.5384 \\
rrents & 5.980589 & 12.27971 & 0.49 & 0.627 & -18.1877 & 30.1489 \\
gexp & -25.03182 & 16.62993 & -1.51 & 0.133 & -57.762 & 7.6983 \\
lifexp & 14.37519 & 43.33462 & 0.33 & 0.740 & -70.913 & 99.6642 \\
inv & -39.27373 & 55.78665 & -0.70 & 0.482 & -149.070 & 70.5227 \\
_cons & 2156.678 & 2778.026 & 0.78 & 0.438 & -3310.892 & 7624.248 \\
sigma_u & 1954.9525 & & & & & \\
sigma_e & 1411.0958 & & & &
\end{tabular}

(Note) Pesaran's test of cross-sectional independence $=-0.710 \quad \mathrm{Pr}=0.4779$

The CD test strongly accepts the null hypothesis of no cross-sectional dependence. 